\title{
Synthesis and characterization of apatite silicated powders with wet precipitation method
}

\author{
Houda Labjar *, Hassan Chaair \\ Engineering laboratory processes and environment, Faculty of Sciences and Technology University Hassan II-Casablanca, B.P.: 146, \\ Mohammedia, 20650, Morocco
}

\begin{abstract}
The synthesis of apatite silicated $\mathrm{Ca} 10(\mathrm{PO} 4) 6-\mathrm{x}(\mathrm{SiO} 4) \mathrm{x}(\mathrm{OH}) 2-\mathrm{x}(\mathrm{SiHA})$ with $0 \leq \mathrm{x} \leq 2$ was investigated using a wet precipitation method followed by heat treatment using calcium carbonate $\mathrm{CaCO} 3$ and phosphoric acid H3PO4 and silicon tetraacetate SiC8H20O4 (TEOS) in medium of water ethanol, with three different silicate concentrations. After drying, the samples are ground and then characterized by different analytical techniques like X-ray Diffraction (XRD), Fourier Transform Infrared Spectroscopy (FTIR) and Scanning electron Microscopy (SEM) and chemical analysis
\end{abstract}

\section{Introduction}

The Synthetic apatite (HA) is one of the most important bioceramics used in orthopedic and dental surgery. Its composition, $\mathrm{Ca}_{10}\left(\mathrm{PO}_{4}\right)_{6}(\mathrm{OH})_{2}$, is very similar to biological apatite that forms the mineral fractions of bone tissue [1]. The apatite is commonly used as a bioceramic due to its biological properties of biocompatibility and bioactivity [2]. The latters can be improved and one way to increase them, would be to use the ability of the apatite to accept a multi- ion of substituting. The calcium phosphate apatites are a family of ionic compounds described by the chemical formula $\mathrm{Me}_{\mathrm{x}}\left(\mathrm{XO}_{4}\right)_{\text {y }}(\mathrm{Y})_{\mathrm{z}}$ wherein $\mathrm{Me}$ is a bivalent metal $\left(\mathrm{Ca}^{2+}\right.$, $\left.\mathrm{Sr}^{2+}, \mathrm{Ba}^{2+}, \mathrm{Pb}^{2+} \ldots\right), \mathrm{XO}_{4}$ is a trivalent anion $\left(\mathrm{PO}_{4}^{3-}\right.$, $\left.\mathrm{AsO}_{4}{ }^{3-}, \mathrm{SiO}_{4}{ }^{4-} \ldots\right)$ and $\mathrm{Y}$ is a monovalent anion $\left(\mathrm{F}^{-}, \mathrm{Cl}^{2}\right.$, $\left.\mathrm{Br}^{-}, \mathrm{I}^{-}, \mathrm{OH}^{-} \ldots\right)$ [3].

The bioactive behavior of the apatite may be improved by approximating the general formula of the bone that is: $1.7 \mathrm{Ca}_{8.3}\left(\mathrm{PO}_{4}\right){ }_{4.3}\left(\mathrm{CO}_{3}\right)_{1.0}\left(\mathrm{HPO}_{4}\right)_{0.7}\left(\mathrm{CO}_{3}\right.$, $\mathrm{OH})$ 0.3. This approach can be achieved by incorporating as component ( $\mathrm{Si}, \mathrm{Mg}, \mathrm{V}, \mathrm{As} . .$.$) . To this end, we are$ interested in the insertion of Silicate on phosphocalcic apatite. The model chosen for this substitution is according to the following theoretical formula [4]:

$$
\mathrm{Ca}_{10}\left(\mathrm{PO}_{6-x}\right)_{6}\left(\mathrm{~S}_{i} \mathrm{O}_{4}\right)_{x}(\mathrm{OH})_{2-x} \text { with } 0 \leq x \leq 2 \text { (1) }
$$

The man has always sought to improve their quality of life with more comfort, our bone system remain an effective way to keep man healthy, since it ensures many functions like support, movement, protection, minerals storage and formation of red blood cells. For all these reasons the science of biomaterials remains thefirst solution for saving lives and this justifies the development of synthetic bone substitutes [5]. According to the physicochemical properties of these synthetic biomaterials, we choose those used for filling bone defects [6]

The incorporation of silicium into the apatitic structure gives significant results on the mechanical properties, as well as the bioactive behavior. The Bioactivity promotes the reaction between the bone and the implant, leading to an excellent osteointegration and ensuring the success of the implant [6].

This increase in biological performance can be attributed to Si-induced changes in the material properties and also to the direct effects of $\mathrm{Si}$ on physiological processes of the bone and connective tissue systems, after our synthesis, we introduce our biomaterials in bone, for studying its effects in biological processes [6].

The silicium ( $\mathrm{Si}$ ) is one of the essential elements. Its importance on bone formation and calcification has been demonstrated through in vitro and in vivo studies [7]. The Si-HA structure corresponds to substitution of phosphate ions $\left(\mathrm{PO}_{4}{ }^{3-}\right)$ by Silicate $\mathrm{SiO}_{4}{ }^{4-}$ ion in the HA crystal structure. Different mechanisms for charge compensation have been suggested $[8,9]$. The most cited was proposed by Gibson et al. with the creation of anionic vacancies at $\mathrm{OH}^{-}$sites [10]. This mechanism leads to Si-HA with the general formula $\mathrm{Ca}_{10}\left(\mathrm{PO}_{4}\right)_{6}$ ${ }_{x}\left(\mathrm{SiO}_{4}\right)_{\mathrm{x}}(\mathrm{OH})_{2-\mathrm{x}}(\mathrm{VOH})_{\mathrm{x}}$, where $\mathrm{x}$ is the molar number of silicate groups introduced into the apatitic structure $(0 \leq$ $\mathrm{x} \leq 2)$ and $\mathrm{VOH}$ represents vacancies to maintain the charge balance[11]. Si-substituted HA (Si-HA) has been synthesized using different methods such as the sol-gel route [12], solid state reactions [13], hydrothermal techniques [14], microwave irradiation [15] and precipitation from aqueous solutions [4,10]. Two reagents are primarily encountered in the literature for the preparation of a silicated apatite: silicon tetraacetate
(Si
$\mathrm{CCH}_{3}$
$\mathrm{COOH})$
4) $[4,10]$,
and 
tetraethylorthosilicatecalled "TEOS" $\left(\mathrm{Si}\left(\mathrm{CH}_{3} \mathrm{OCH}_{2}\right){ }_{4}\right)$ $[16,17]$

The advantages and the disadvantages of aqueous precipitation methods are already described in the literature; it is the most talented route owing to its ease in experiment operations, low working temperature, high percentages of pure products and inexpensive equipment requirement [18]. The objective of this work is to synthesize the pure apatite silicated with controlled silicate portions by aqueous precipitation method.

\section{Material and Methods}

\subsection{Materials /numbering}

The objective of this work is to synthesize the pure apatite silicated with controlled silicate portions by aqueous precipitation method. The principle of synthesis by this method is to add an anionic solution (phosphate and silicate) to another ionic solution initially present in the reactor such as calcium solution. The reaction is maintained in aqueous ethanol medium.

We have to respect the experimental conditions such as temperature, the $\mathrm{pH}$ of reaction and the time of maturation. For all these reasons the precipitation reactions were carried at $80^{\circ} \mathrm{C}$ and the $\mathrm{pH}$ was maintained at 10 by the addition of ammonia solution. After a complete mixing of the reactants, the suspensions were shaked for $4 \mathrm{~h}$. The resulting precipitates were filtered, washed and dried at $900^{\circ} \mathrm{C}$ for $4 \mathrm{~h}$. After drying, the samples were ground and then characterized by different analytical techniques like X-ray Diffraction (XRD), Fourier Transform IR Spectroscopy (FTIR), Scanning Electron Microscopy (SEM) and Chemical analysis.

In the first time, a pure $\mathrm{HAC} \mathrm{Ca}_{10}\left(\mathrm{PO}_{4}\right)_{6}(\mathrm{OH})_{2}$ was prepared to be used as a reference material for further SiHA syntheses and analyses. The powders were prepared by aqueous precipitation method using calcium carbonate $\mathrm{CaCO}_{3}$, phosphoric acid $\mathrm{H}_{3} \mathrm{PO}_{4}$ and $\mathrm{Si}\left(\mathrm{CH}_{3} \mathrm{CH}_{2} \mathrm{O}\right)_{4}$ TEOS as reagents, and solvents.

The quantities of reagents were calculated assuming that one mole of phosphate was substituted by one mole of silicate (table1), while maintaining our stoichiometric apatite, reagent molar ratio of $10 / 6$ was used $\mathrm{Ca} / \mathrm{P}+\mathrm{Si}=1.67$, and the substitution mechanism (equation1) proposed for this synthesis depends on this equation:

$$
\begin{gathered}
10 \mathrm{Ca}^{2+}+(6-x) \mathrm{PO}_{4}{ }^{3-}+x\left(\mathrm{SiO}_{4}{ }^{4-}\right)+(2-x) \mathrm{OH}^{-}------- \\
\mathrm{Ca}_{10}\left(\mathrm{PO}_{4}\right)_{6-x}\left(\mathrm{SiO}_{4}\right)_{x}(\mathrm{OH})_{2-x}
\end{gathered}
$$

The ratio $\mathrm{Ca} / \mathrm{P}$ is determined in the first time by the dosage of calcium, the latter is carried out by complexometry with Ethylene Diamine Tetraacetic Acid (EDTA) in the presence of ammonia [19]. The excess EDTA is then dosed with a standard solution of zinc chloride. The turn/hue indicator is Eriochrome black. The errormarging on the calcium content is of the order of $0.5 \%$.

In the second time the dosage of the phosphore, in the solids studied, the phosphorus may be present in the form of orthophosphoric groups $\mathrm{PO}_{4}{ }^{3-}$ or hydrogenphosphoric groups $\mathrm{HPO}_{4}{ }^{2-}$. The ions $\left(\mathrm{PO}_{4}{ }^{3-}\right)$ are usually measured by color colorimetry $[20,21]$. The principle of this method consists in measuring, in an acid medium, the optical density (absorbance) of the yellow wish coloration of the phosphovanadomolybdic complex $\left(\mathrm{VO}_{3}\left[\mathrm{P}\left(\mathrm{Mo}_{3} \mathrm{O}_{10}\right) 4\right]\right)$ at $\lambda=460 \mathrm{~nm}$. (Table1).

The principle of synthesis by precipitation in aqueous solution of calcium phosphates apatite is to add an ionic solution like phosphate and silicate solution to another ionic solution initially present in the reactor like calcium solution. The choice of reagents is important in order to ensure a good homogeneity of the reaction. All

the solutions must be mixed together.

However, the dissolution of a silicate precursor is complicated, for this reason we chose work in an aqueous ethanol medium.

\begin{tabular}{|c|c|c|c|c|c|c|c|c|c|c|}
\hline Sample & $\mathrm{X}$ & $\begin{array}{l}\mathrm{CaCO}_{3} \\
(\mathrm{~mol})\end{array}$ & $\begin{array}{c}\mathrm{H}_{3} \mathrm{PO}_{4} \\
(\mathrm{~mol})\end{array}$ & $\begin{array}{r}\text { TEOS } \\
(\mathrm{mol})\end{array}$ & $\mathrm{pH}$ & $\mathrm{Ca} / \mathrm{P}$ & $\begin{array}{c}\mathrm{Ca} / \\
\mathrm{P}+\mathrm{Si}\end{array}$ & $\begin{array}{c}\mathrm{Ca} / \mathrm{P} \\
\mathrm{cal}\end{array}$ & $\begin{array}{l}\text { Chemical formula } \\
\text { of xSiHA }\end{array}$ & $\begin{array}{l}\text { Chemical formula } \\
\text { of xSiHAcal }\end{array}$ \\
\hline HA & 0 & 0.100 & 0.059 & 0 & 10 & 1.67 & 1.67 & 1.65 & $\begin{array}{c}\mathrm{Ca}_{10}\left(\mathrm{PO}_{4}\right)_{6} \\
\mathrm{OH}_{2}\end{array}$ & $\begin{array}{c}\mathrm{Ca} 9_{.8}\left(\mathrm{PO}_{4}\right)_{5,94} \\
\quad(\mathrm{OH})_{1.85}\end{array}$ \\
\hline $0.5 \mathrm{Si} \mathrm{HA}$ & 0.5 & 0.100 & 0.055 & 0.005 & 10 & 1.81 & 1.67 & 1.79 & $\begin{array}{c}\mathrm{Ca}_{10}\left(\mathrm{PO}_{4}\right)_{5.5} \\
\left(\mathrm{SiO}_{4}\right)_{0.5} \\
(\mathrm{OH})_{1.5}(\mathrm{VOH})_{0,5}\end{array}$ & $\begin{array}{c}\mathrm{Ca}_{9.74}\left(\mathrm{PO}_{4}\right)_{5,44} \\
\left(\mathrm{SiO}_{4}\right)_{0,56}(\mathrm{OH})_{0.44}\end{array}$ \\
\hline $1 \mathrm{Si} \mathrm{HA}$ & 1 & 0.100 & 0.051 & 0.009 & 10 & 2 & 1.67 & 1.95 & $\begin{array}{c}\mathrm{Ca}_{10}\left(\mathrm{PO}_{4}\right)_{4.5} \\
\left(\mathrm{SiO}_{4}\right) 1(\mathrm{OH}) \\
(\mathrm{VOH})_{1}\end{array}$ & $\begin{array}{l}\mathrm{Ca} 9.71(\mathrm{PO} 4)_{4.96} \\
\left(\mathrm{SiO}_{4}\right)_{1.04}(\mathrm{OH})\end{array}$ \\
\hline $2 \mathrm{Si} \mathrm{HA}$ & 2 & 0.100 & 0.04 & 0.02 & 10 & 2.5 & 1.67 & 2.35 & $\begin{array}{c}\mathrm{Ca} 10\left(\mathrm{PO}_{4}\right)_{4} \\
\left(\mathrm{SiO}_{4}\right)_{2}(\mathrm{OH})_{0}(\mathrm{VOH})_{2}\end{array}$ & $\begin{array}{c}\mathrm{Ca} 9.7\left(\mathrm{PO}_{4}\right)_{4.09} \\
\left(\mathrm{SiO}_{4}\right)_{1.91}(\mathrm{OH})_{0.09}\end{array}$ \\
\hline
\end{tabular}

Table 1. The quantities of reagents 


\subsection{Methods of characterization}

The X-ray diffraction (XRD) patterns of sintered Ha and SiHa is archieved using by a D8 advance Eco de Brucker diffractometer. Data were collected over the $2 \theta$ range 5 ${ }^{\circ} \mathrm{C}-70{ }^{\circ} \mathrm{C}$ with step size of $0.06^{\circ}$ and count time of $1 \mathrm{~s}$, are shown in (figure 1). The XRD for the materials appeared to be similar; the incorporation of Silicium into the $\mathrm{Ha}$ did not have a direct effect on the phase composition, and we notice that we don't have secondary phase.

The first observation on X-Ray diffraction shows that the diffraction peaks lose intensity with increasing silicate content, and we also observe in the peaks a decrease of crystallinity and crystallite size (Figure 2).

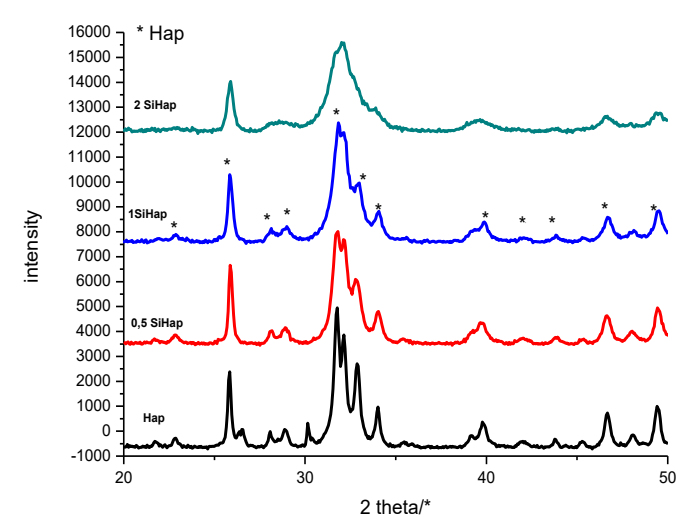

Fig. 1. X-ray powder diffraction patterns of HA and Si-HA powders calcined at $900^{\circ}$

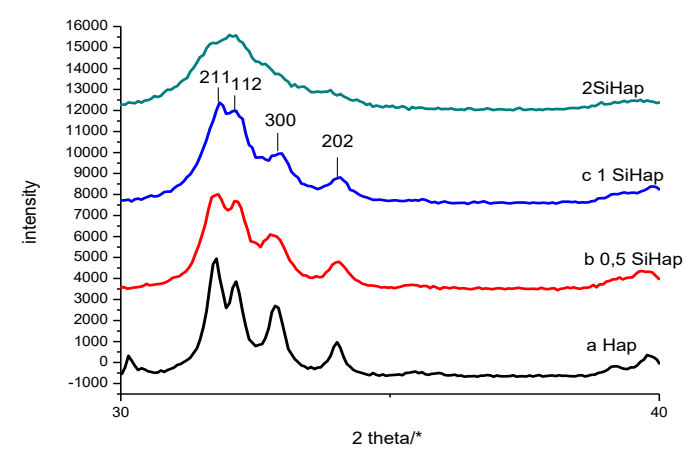

Fig. 2. Peak shift for Si-HA samples with increasing silicon content (a) pure $\mathrm{HA}$, (b) $0.5 \mathrm{SiHA}$, (c) $1 \mathrm{SiHA}$ and (d) $2 \mathrm{SiHA}$ calcined at $900^{\circ} \mathrm{C}$

The lattice parameters of pure Ha and Si substituted apatite sample are listed in table 2 . The crystalline phases of samples were determined using X-ray diffraction (XRD). They were identified by means of the expert proof. We observe that the parameters of Si Hap are larger than those of pure $\mathrm{Ha}$.

The substitution of PO43- by $\mathrm{SiO} 44-$ is assumed to contribute to the increase in the lattice parameters of the Si-HA materials. Parameters a and c increase when the Si substitution increases. This increase of parameters can be explained to appear logical considering that the ionic radius of $\mathrm{Si} 4+(0.042 \mathrm{~nm})$ is larger than that of $\mathrm{P} 5+$ $(0.035 \mathrm{~nm})[22]$. However, the observed variations in the lattice parameters and crystallite sizes did not change the intensity of the XRD peaks. This can also be understood considering that apparent intensity changes in the XRD peaks are only expected when there is an extensive atomic substitution of fairly different sized ions. In the present case, Si and Pnare adjacent to each other in the periodic table; differing only by one atomic number and the Si levels are relatively low. This could be attributed to different charge compensation mechanism for isomorphous substitution of PO43- by $\mathrm{SiO} 44-$.

Table 2. Crystallite sizes along a-axis and c-axis of calcined HA and SiHA using Scherrer's equation

\begin{tabular}{|c|c|c|c|c|}
\hline Crystallite sizes & $\begin{array}{c}\text { Space } \\
\text { Groupe }\end{array}$ & $\mathrm{a}(\mathrm{nm})$ & $\mathrm{c}(\mathrm{nm})$ & $\mathrm{V}(\mathrm{nm} 3)$ \\
\hline HA & $\mathrm{P} 63 / \mathrm{m}$ & 9.4180 & 6.8842 & 528.81 \\
\hline & $\mathrm{P} 63 / \mathrm{m}$ & 9.4282 & 6.8846 & 529.98 \\
\hline & & & & \\
\hline 1SiHA & $\mathrm{P} 63 / \mathrm{m}$ & 9.4285 & 6.8862 & 530.14 \\
\hline 2SiHA & $\mathrm{P} 63 / \mathrm{m}$ & 9.4288 & 6.8871 & 530.24 \\
\hline
\end{tabular}

The Fourier Transform Infrared (FTIR) spectra is fulfilled using the iraffinity- $1 \mathrm{~s}$ spectrometer, at resolution of $4 \mathrm{~cm}-1$ averaging 100 scans. Figure (3) shows the FTIR spectra of powders calcined at $900^{\circ} \mathrm{C}$ for $4 \mathrm{~h}$. The FTIR was used to study the effect of the silicate substitution on the different functional groups such as phosphate and hydroxyl. The intense bands at 1092, 1036, and $964 \mathrm{~cm}-1$ correspond to P-O stretching vibration modes. The doublet at $605-560 \mathrm{~cm}-1$ and the band at $469 \mathrm{~cm}-1$ corresponds to $\mathrm{O}-\mathrm{P}-\mathrm{O}$ bending modes. The bands at 3560 and $632 \mathrm{~cm}-1$ were assigned to the stretching and vibration modes, respectively, of the hydroxide groups $1370-1600 \mathrm{~cm}-1$ were assigned to the vibrations of $\mathrm{CO} 32$ - groups. In the $2 \mathrm{SiHa}$ we observe new band appearing at $880 \mathrm{~cm}-1$ this was assigned to $\mathrm{Si}-$ $\mathrm{O}$ in the $\mathrm{SiO} 44-$. (Figure 3).

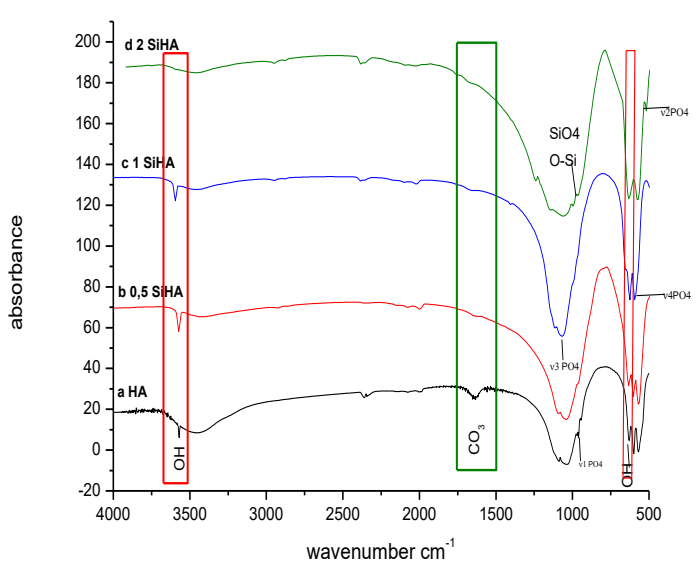

Fig. 3. FTIR spectra of the powders: (a) pure HA, (b) 0.5 $\mathrm{SiHA}$, (c) $1 \mathrm{SiHA}$ and (d) $2 \mathrm{SiHA}$ calcined at $900^{\circ} \mathrm{C}$.

SEM micrographs data and EDS (Energy Dispersive X-ray Spectroscopy) of the HA and SiHA powders 
calcined at $900^{\circ} \mathrm{C}$ are given in figure 4 . This shows the morphology of the substituted apatites (figure 4-b). The crystals of Si substituted apatite became larger than those of hydroxyapatite. Figue 4 shows that HA is spheroidalshaped crystallites. However, increase with the $\mathrm{Si}$ content, the crystals started elongating and SiHA powder shows ellipsoidal shape morphology. This form facilitates its insertion into the bone tissue for the filling of bone defects, suggesting that the growth perpendicular to the c-axis is easier in the presence of $\mathrm{Si}$.

The EDS shows that our samples are constituting from calcium and phosphore and silisium.
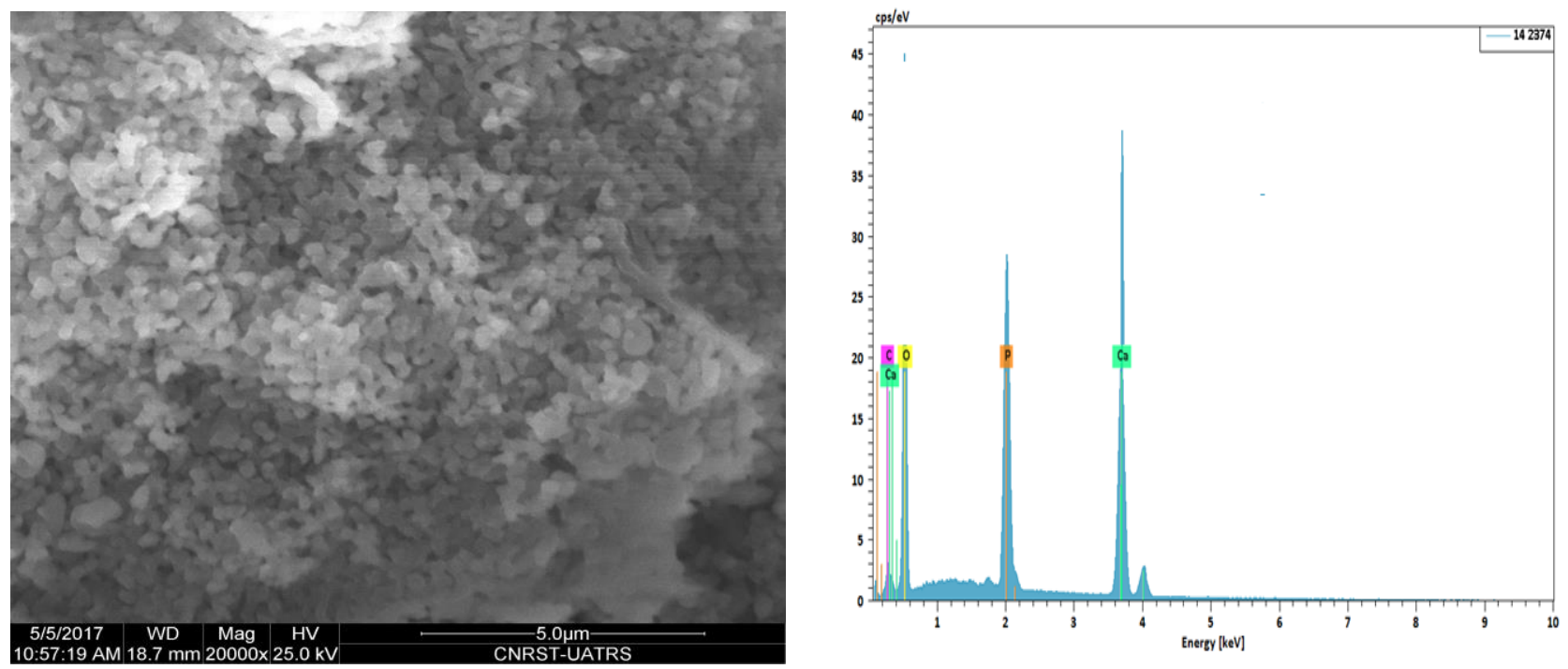

a. EDS revealed that our Ha have $39.61 \mathrm{wt} \%$ of Calcium,23.8 wt \% of Phosphate.
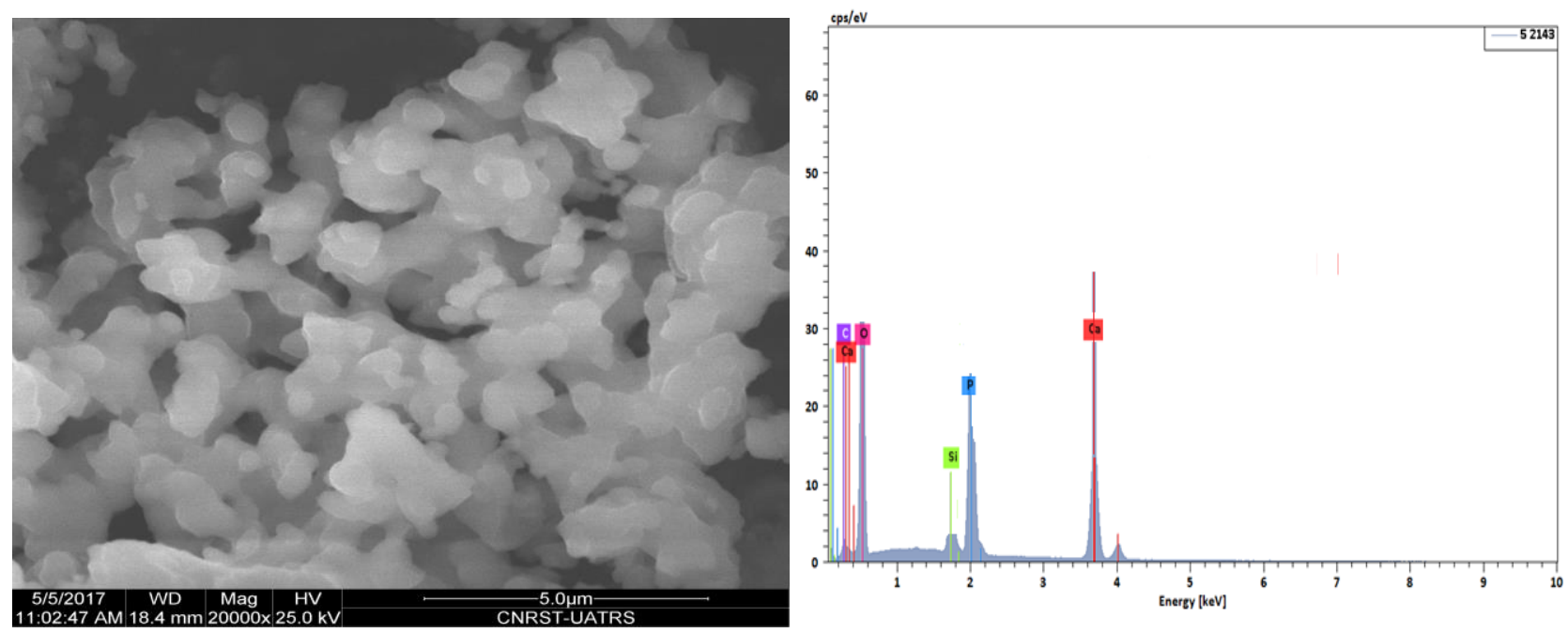

b. EDS revealed that our Si Ha have $39.61 \mathrm{wt} \%$ of Calcium,21.8 wt \% of Phosphate and $3.2 \mathrm{wt} \%$ of silicium

Fig. 4. SEM micrographs and EDS (Energy Dispersive X-ray Spectroscopy) of the powders: (a) HA, (b) $0.5 \mathrm{SiHa}$

\section{Conclusion}

This paper presents the synthesis of silicate apatite with precipitation wet method using carbonate calcium $\mathrm{CaCO}_{3}$ and phosphoric acid $\mathrm{H}_{3} \mathrm{PO}_{4}$ and TEOS. Silicate is incorporated in the apatite lattice and its stoichiometry was controlled, in the objective of obtaining biomaterials having an improved biocompatibility for the insertion in the bone. This special morphology observed in SEM micrographs and the results obtained in XRD and FTIR and chemical analysis, all these results are essential for the biological application of our biomaterial.

\section{References}

1. O.Britel, M.Hamad, B.Sallek, H.Chaair, K.Digua, H.Ouadadess, Phosphorus Sulfur Silicon, (2006) 181-325-336.

2. D.Arcos, J.Rodríguez-Carvajal, M.Vallet-Regí, Chem. Mat., 16(11)(2004) 2300-2308.

3. O.Britel, M.Hamad, H.Chaair, S.Belouafa, B.Sallek, K.Digua, Phosphorus Sulfur Silicon, 179 (2004) 1857-1865. 
4. M.Palard, E.Champion, S.Foucaud, Journal Solid. State. Chem, 181(8) (2008) 1950-1960.

5. E.M.Carlisle, Silicon: a possible factor in bone calcification. Science, 167(1970) 279-80

6. H.Labjar, F.Faouzi, A.Driouich, I.Akhiyat, K.Digua, C.Rifki, H.Chaair, Der Pharma Chemica, 9(12) (2017) 137-143

7. J.C.Eliott, Rev. Mineral. Geochem., 48 (2002) 427454

8. J.Gómez-Morales, J. Torrent-Burgués, T.Boix, J.Fraile, R.Rodríguez-Clemente, Crys. Res. Technol, 36 (2001) 15-26.

9. H.Labjar, W.Cherif, S.Nadir, K.Digua, B.Sallek, H.Chaair, Journal of Taibah. Univ. Sci, 10(5) (2016) 745-754.

10. Gibson, S.M.Best,W.Bonfield, journal Biomed Mater Res, 44(4) (1999) 422-428

11. S.Gomes, J.M.Nedelec, E.Jallot,D .Sheptyakov, G. Renaudin, Silicon location in silicate substituted caclium phosphate ceramics determined by neutron diffraction,Cryst. Growth. Des 11 (2011) 401726.

12. D.Marchat, M.Zymelka, C.Coelho, L.Gremillard, L.Joly-Pottuz, F.Babonneau, C.Esnouf, J.Chevalier, D.Bernacheassollant, Acta. Bio. Mat, 9 (2013) 6992-7004.

13. N.Hijón, M.Victoria Cabañas, J.Peña, M.ValletRegí, Dip coated silicon-substituted hydroxyapatite films. ActaBiomater, 2 (2006) 567-74.

14. A.Aminian, M.Hashjin, A.Samadikuchaksaraei, F.Bakhshi, F.Gorji- pour, A.Farzadi, F.Moztarzadeh, M.Schmcker, Synthesis of siliconsubstituted hydroxyapatite by a hydrothermal method with two different phosphorous sources, Ceram. Int, 37 (2011) 1219-2122

15. D.Arcos, J.Rodríguez-Carvajal, M.Vallet-Regí, The effect of silicon incorporation on the hydroxylapatitestructure.A neutron diffraction study. Solid. State. Sci,6 (2004) 987-94.

16. K.Nakata,T.Kubo, C.Numako, T.Onoki, A.Nakahira, MaterialsTransactions,5 (2009) 10461049

17. S.K.Padmanabhan, E.UlHaq, A.Licciulli, Rapid synthesis and characterization of silicon substituted nano-hydroxyapatite using microwave irradiation. Current Applied Physics 14 (2014) 87-92

18. A.ElYacoubi, A.Massit, M.Fathi, B.Chafik El Idrissi, K.Yamni, Volume 7 Issue 11 Ver. II. Nov( 2014)2278-5736 PP 24-29

19. O. Victor, V.O. Ajibola, E.B.Agbaji, A.A. GiwaInternational Journal of Nano and Material Sciences, 4(1) (2015)39-54

20. G.Charlot,Les méthodes de la chimie analytique : Analyse quantitative et minérale. 5ième édition, Masson, (1966)

21. A.Gee, V. R.Dietz,Anal. Chem., vol. 25 (1953) pp. 132.
22. R.J.Friederichs, H.F.Chappell, D.V.Shepherd, S.M.Best, J. R. Soc. Inter, 12 (2015) 1-20. 